Mycologia, 98(4), 2006, pp. 637-649.

(C) 2006 by The Mycological Society of America, Lawrence, KS 66044-8897

\title{
Two new pycnidial members of the Atractiellales: Basidiopycnis hyalina and Proceropycnis pinicola ${ }^{1}$
}

Franz Oberwinkler

Universität Tübingen, Lehrstuhl Spezielle Botanik und Mykologie, Auf der Morgenstelle 1, D-72076, Tübingen, Germany

Roland Kirschner

Botanisches Institut, J.W. Goethe-Universität, Siesmayerstraße 70, 60323 Frankfurt am Main, Germany

Francisco Arenal

Manuel Villarreal

Víctor Rubio

Dpartamento de Protección Vegetal, Centro Ciencias Medioambientales (CCMA-CSIC), Serrano, 115bis, E28006 Madrid, Spain

Dominik Begerow ${ }^{2}$

Robert Bauer

Universität Tübingen, Lehrstuhl Spezielle Botanik und Mykologie, Auf der Morgenstelle 1, D-72076, Tübingen, Germany

Abstract: Two new genera, Basidiopycnis and Proceropycnis, and two new species, Basidiopycnis hyalina and Proceropycnis pinicola, are described. An integrated analysis of morphological, ecological, ultrastructural and molecular data indicates that the new taxa belong to the Atractiellales. Relevant characteristics of the new genera and species are discussed and compared with those of related taxa.

Key words: Atractiellales, bark beetles, molecular phylogeny, symplechosomes, ultrastructure, urediniomycetes

\section{INTRODUCTION}

The Atractiellales sensu Oberwinkler and Bauer (1989) contain the teleomorphic genera Helicogloea Pat., Saccoblastia Möller, Atractiella Sacc. and Phleogena Link. All members are phragmobasidiate and characterized by having symplechosomes (Bauer and Oberwinkler 1991, Oberwinkler and Bauer 1989). The septal pore apparatus consists of a simple pore surrounded by an organelle-free zone. Except for Saccoblastia, the organelle-free zone is delimited by

Accepted for publication 10 May 2006.

${ }^{1}$ Part 227 in the series "Studies in Heterobasidiomycetes" from the Botanical Institute, University of Tübingen.

${ }^{2}$ Corresponding author. E-mail: dominik.begerow@uni-tuebingen. de atractosomes in a more or less circular arrangement (Weiss et al 2004). Nucleotide sequence analyses confirm the monophyly of this group (Swann et al 2001). Morphologically, however, the members of Atractiellales possess a high degree of divergence. Thus Helicogloea and Saccoblastia form resupinate fruit bodies, whereas Atractiella and Phleogena develop stilboid fruit bodies (Oberwinkler and Bauer 1989). In addition several anamorphic hyphomycetes, such as Infundibura adhaerens Nag Raj \& W.B. Kendr. and Leucogloea compressa (Ellis \& Everh.) R. Kirschner, recently were ascribed to the Atractiellales (Bandoni and Inderbitzin 2002, Kirschner 2004).

Bark beetle galleries recently have been discovered as a cryptic habitat of previously unknown taxa of basidiomycetes (Kirschner 2001; Kirschner et al 1999, 2001a, b, c). Additional collections of fungi associated with conifers infested by beetles revealed additional hitherto undescribed taxa and shed a new light on the diversity of the Atractiellales. Here we describe two new atractielloid species forming pycnidia.

\section{MATERIALS AND METHODS}

Fungal isolation and growth conditions. - Samples of bark with beetles and their galleries were collected in Germany, Italy and Switzerland and treated for the detection of fungi carried by the beetles by cultivating methods as described in Kirschner (2001). Samples of bark and wood of Pinus spp. infested by beetles were collected in Spain, China and Taiwan and examined for the presence of fungi with a dissecting microscope. Conidial masses from the apex of the pycnidia growing in situ in the bark and beetle galleries were transferred with a needle to Petri dishes containing autoclaved pieces of spruce twigs (Picea abies [L.] Karst.) embedded in $1.5 \%$ water agar or malt-extract agar (MEA) plates (containing $20 \mathrm{~g}$ Difco agar and $20 \mathrm{~g}$ Merck malt extract in $1000 \mathrm{~mL}$ distilled water). The plates were incubated at $24 \mathrm{C}$ and $80 \% \mathrm{RH} 14 \mathrm{~d}$ and preserved as frozen agar plugs in $20 \%$ glycerol vials at $-80 \mathrm{C}$. Dry material was deposited at the herbarium of the University of Alcalá de Henares (AH), KUN, TNM and TUB). Living cultures are deposited at CCMA-CSIC, CIBE-MSD, TUB and CBS culture collections.

Light microscopy.-Specimens were prepared on slides with lactophenol cotton blue or $5 \% \mathrm{KOH}$ with staining with $1 \%$ aqueous phloxine and observed under a light microscope. Photographs, drawings and measurements were done with light microscopy.

Electron microscopy.-For transmission electron micros- 
TABLE I. Numbers of bark beetles carrying Basidiopycnis hyalina

\begin{tabular}{lccc}
\hline \hline \multicolumn{1}{c}{ Beetle species } & $\begin{array}{c}\text { Number of beetles } \\
\text { carrying B. hyalina }\end{array}$ & $\begin{array}{c}\text { Percentage of beetles } \\
\text { carrying B. hyalina }\end{array}$ & \begin{tabular}{c} 
Total number of beetles \\
\hline Crypturgus cinereus
\end{tabular} \\
Crypturgus pusillus & 6 & 4.7 & 127 \\
Dryocoetes autographus & 17 & 5.1 & 332 \\
Hylurgops palliatus & 8 & 2.4 & 334 \\
Ips typographus & 3 & 0.7 & 437 \\
Orthotomicus laricis & 37 & 3.2 & 1128 \\
Pityogenes chalcographus & 3 & 0.6 & 495 \\
Polygraphus poligraphus & 67 & 6.8 & 976 \\
Trypodendron lineatum & 5 & 7.5 & 67 \\
\hline
\end{tabular}

Beetles were collected 1994-1998 from bark of Picea abies and Pinus sylvestris in localities of Germany, Italy and Switzerland. The fungus was detected in culture after placing beetles individually into Petri dishes with media.

copy (TEM) samples were fixed overnight with $2 \%$ glutaraldehyde in $0.1 \mathrm{M}$ sodium cacodylate buffer $(\mathrm{pH} 7.2)$ at $20 \mathrm{C}$. After six transfers in $0.1 \mathrm{M}$ sodium cacodylate buffer samples were postfixed in $1 \%$ osmium tetroxide in the same buffer $1 \mathrm{~h}$ in the dark, washed in bidistilled water and stained $1 \%$ aquaeous uranyl acetate $1 \mathrm{~h}$ in the dark. After five consecutive washes in bidistilled water samples were dehydrated in acetone, using $10 \mathrm{~min}$ transfers at 10, 25, 50, 70, 95\% acetone, and three times in $100 \%$ acetone. Samples were embedded in Spurr's plastic and sectioned with a diamond knife. Ultrathin serial sections were mounted on formvar-coated, single-slot copper grids, stained with lead citrate at room temperature $5 \mathrm{~min}$, and washed with bidistilled water. The samples were studied with a Zeiss EM 109 transmission electron microscope operating at $80 \mathrm{kV}$.

DNA amplification and sequencing.-DNA extraction and amplification procedures were carried out as described in Begerow et al (1997) and Boysen et al (1996). The primers used for amplification of SSU rDNA were NS1NS8 (White et al 1990) and NS17UCB to NS24UCB (Gargas and Taylor 1992). ITS sequences of Atractiellaceae were obtained with primers ITS1 and ITS4 (White et al 1990). PCR products were purified with $\mathrm{GFX}^{\mathrm{TM}}$ PCR gel band purification kit (Amersham Pharmacia Biotech Inc., USA) or QIAquick ${ }^{\mathrm{TM}}$ purification kit (QIAGEN, Germany). All regions amplified were sequenced with the ABI PRISM Dye Terminator Cycle Sequencing Kit, on automatic sequencer ABI PRISM 373 or ABI PRISM 3100. New sequences are deposited at GenBank (DQ198779-DQ198798).

Phylogenetic analysis. - The SSU alignment was built with MAFFT 3.85 (Katoh et al 2002) with the accurate and iterative refinement method. After trimming ends the alignment consisted of $1701 \mathrm{bp}$. Phylogenetic analyses were carried out with PAUP* 4.0b10 (Swofford 1998) on a G5 Macintosh computer. Modeltest 3.0 (Posada and Crandall 1998) was carried out to determine a model of DNA substitution that fits the data set, and GTRIG was selected from the Akaike information criterion (base frequencies: $\pi_{\mathrm{A}}=0.2498, \pi_{\mathrm{C}}=0.2069, \pi_{\mathrm{G}}=0.2670$, $\pi_{\mathrm{T}}=0.2763$; substitution rates: $\mathrm{A} / \mathrm{C}=0.9884, \mathrm{G} / \mathrm{T}=$ $1.0000, \mathrm{~A} / \mathrm{G}=3.0591, \mathrm{~A} / \mathrm{T}=1.6186, \mathrm{C} / \mathrm{G}=1.2350$, $\mathrm{C} / \mathrm{T}=5.3811$; gamma shape parameter $=0.4996$; percentage of invariant sites $=0.3527)$. Neighbor joining analysis was done with genetic distances according to the specified substitution model. Parsimony analysis was done in two steps, where the first with 100 000 random additions without swapping resulted in nine islands and TBR swapping confirmed these islands to be most parsimonious with 2,378 steps $(\mathrm{CI}=0.449$; $\mathrm{RI}=0.634 ; \mathrm{RC}=0.284)$. One thousand replicates were used for bootstrap analyses. The ITS alignment was built with Muscle v3.2 (Edgar 2004) and consisted of $408 \mathrm{bp}$. Pairwise distances were calculated based on the K2Pmodel after removing five positions with gaps. The alignments are available on request.

\section{RESULTS AND DISCUSSION}

Fungal isolation and growth conditions.-Two species of fungi with superficial pycnidium-like structures and affinities to the Atractiellales were found in conifer samples infested by bark beetles: a pycnidial sexual species and its synnematous anamorph in samples from central Europe and a pycnidial anamorph in samples from Spain, China and Taiwan. Frequencies of detection of the sexual basidiomycete from different bark beetles in central Europe are provided (TABLE I). The frequencies of other associated fungi were shown in Kirschner (2001). Both species developed pycnidial structures on autoclaved spruce twigs embedded in water agar, but on conventional media like MEA only reduced conidiophores developed. The sexual species produced basidiomata in culture only in the presence of other fungi (e.g. Graphium sp., Penicillium sp., Trichoderma sp). The pycnidial wall of both species is composed of one or two layers of parallel, hyaline and sparsely 

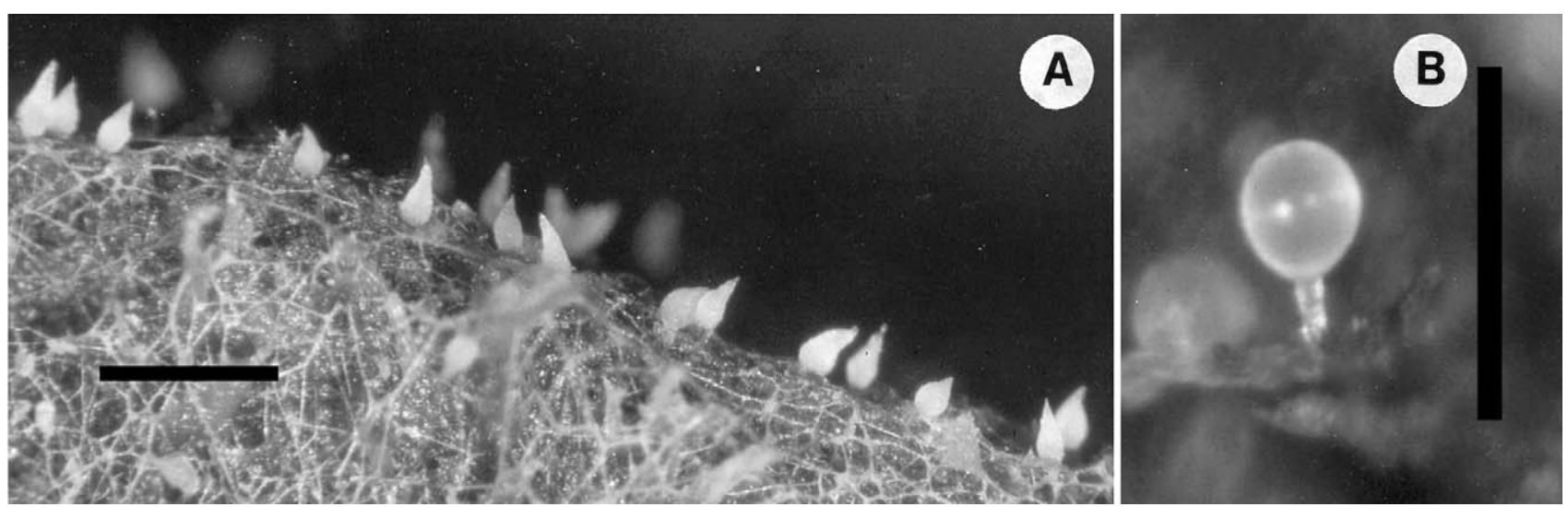

FIG. 1. Photographs of Basidiopycnis hyalina. A. Teleomorph. Basidiomata in culture. B. Anamorph. Synnema with conidial mass in an apical slimy drop in culture. Bars: $A=500 \mu \mathrm{m}, \mathrm{B}=300 \mu \mathrm{m}$.

branched hyphae that easily can be separated from each other. In the pycnidium-like structures of one species, however, basidia developed, and conidiophores developed in the pycnidia of the other species.

Taxonomy._-Using morphological, ultrastructural and molecular methods we assigned both species to the Atractiellales and propose two new genera and species.

Basidiopycnis Oberw., R. Kirschner, R. Bauer, Begerow et Arenal, gen. nov.

Basidiomata cornuta, pycnidioidea, hyalina vel pallide colorata, ex hyphis sterilibus marginalibus apicaliter convergentibus et fascicolo hypharum et basidiorum composita. Basidia transversaliter 3-septata, sterigmatibus minutis rectis. Basidiosporae hyalinae. Status anamorphosis cellulis conidiogenis annellidicis et conidiis in massa mucosa aggregatis.

Typus generis. Basidiopycnis hyalina Oberw., R. Kirschner, R. Bauer, Begerow et Arenal, in opere ipso descripta.

Basidiomata pycnidium-like, cornute, hyaline or white, composed of sterile, septate, marginal hyphae converging to the apex, and of a central fascicle of branched hyphae with transversally septate basidia with short, straight sterigmata. Basidiospores hyaline. Anamorph with annellidic conidiogenous cells and conidia aggregating in slimy masses.

Basidiopycnis hyalina Oberw., R. Kirschner, R. Bauer, Begerow et Arenal, sp. nov. FIGs. 1-2 Etym. Referring to the presence of basidia in hyaline pycnidium-like basidiomata. Basidiomata superficialia, cornuta, pycnidioidea, hyalina, 80$225 \times 40-100 \mu \mathrm{m}$, ex hyphis sterilibus marginalibus apicaliter convergentibus et fasciculo hy- pharum et basidiorum composita. Hyphae hyalinae, laeves, septatae, efibulatae, $1.5-3 \mu \mathrm{m}$ diam. Basidia cylindracea, recta vel leniter curvata, 3septata, $48-70 \times 3-5 \mu \mathrm{m}$, sterigmatibus minutis rectis. Basidiosporae hyalinae, laeves, aseptatae, clavatae, 20-45 $\times 2.5-4 \mu \mathrm{m}$, in massa mucosa aggregatae. Status anamorphosis synnematosus, hyalinus, ex stipite et apparato apicali conidiogeno compositus. Conidiophora irregulariter ramosa, hyalina, 120-240 $\mu \mathrm{m}$ alta. Cellulae conidiogenae terminales, annellidicae, cylindraceae, 40-130 × $3.5 \mu \mathrm{m}$. Conidia hyalina, laevia, unicellularia, cylindrica, basibus truncatis, $5-15 \times 2.5-3 \mu \mathrm{m}$, in massa mucosa hyalina aggregata.

Basidiomata pycnidium-like, conical, hyaline or white, in situ 80-225 $\times 40-100 \mu \mathrm{m}$, composed of sterile marginal hyphae which are septate, 2-3.5 $\mu \mathrm{m}$ diam, and converge at the apex, and of a central fascicle of branched hyphae with basidia. All hyphae hyaline, smooth, predominantly thinwalled or only slightly thick-walled, without clamps at the septa, 1.5-3 $\mu \mathrm{m}$ (Figs. 1A, 2A). Basidia cylindrical, tapering to the base, straight or slightly curved, with three transversal septa, 48-70 × 3$5 \mu \mathrm{m}$, with short, straight sterigmata. Basidiospores hyaline, smooth, aseptate, clavate, with obtuse apex and narrowing base, 20-45 $\times 2.5-4 \mu \mathrm{m}$, passively released from the basidia and aggregating in a hyaline to white slimy drop at the apex of the basidioma (FIG. 2A, B).

Anamorph hyphomycetous, conidiomata mostly synnematous, hyaline, in culture $120-240 \mu \mathrm{m}$ high, stipe 24-30 $\mu \mathrm{m}$ wide, composed of sparsely branched, smooth, parallel hyphae. Conidiophores synnematous or mononematous, hyaline, irregularly branched. Branches basally inserted with a constriction and the first septum several micrometers distant from the insertion point. Conidiogenous cells terminal, cylin- 

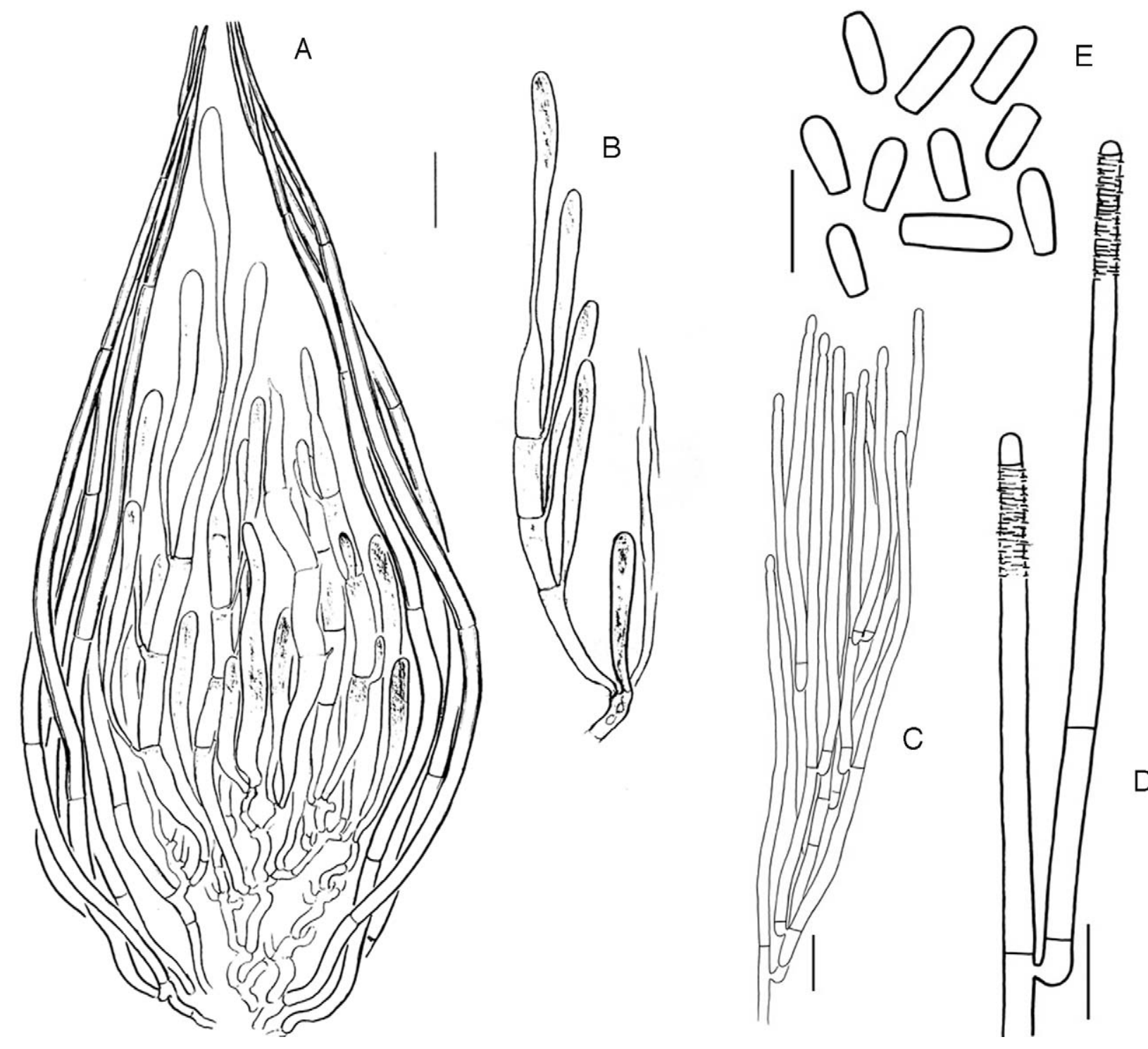

FIg. 2. Drawings of Basidiopycnis hyalina. A. Pycnidioid basidiocarp of the holotype. B. Basidium in detail. C. Conidiophore. Culture from Pityogenes chalcographus from Picea abies, Bad Waldsee, Germany, leg. 16 Oct. 1996, cult. 18 Oct 1996, (not preserved) R. Kirschner. D. Two conidiogenous cells showing annellations. Culture from Pityogenes chalcographus from Picea abies, Tübingen, Germany, leg. 1 May 1996, cult. 3 May 1996, R. Kirschner156. E. Conidia. Culture from Pityogenes chalcographus from Picea abies, Tübingen, Germany, leg. 1 May 1996, cult. 3. May 1996, R. Kirschner156. Bars $=10 \mu \mathrm{m}$.

drical, annellidic, 40-130 $\times 2-3.5 \mu \mathrm{m}$. Conidia hyaline, smooth, 1-celled, cylindrical, with rounded apex and truncate base, $5-15 \times 2.5-3 \mu \mathrm{m}$, aggregating in hyaline or white, slimy heads $(30-400 \mu \mathrm{m}$ diam), germinating with hyphae (FIGS. 1B, 2C-E). Yeast stage not found.

Holotype. Germany, Bayern, Allgäu, Oberjoch, ca. $1500 \mathrm{~m}$, in galleries of bark beetles in bark of Picea abies, 3 Oct 1993, F. Oberwinkler 44664 (TUB). Living culture of this specimen is deposited in the culture collection of the Botanical Institute of the University of Tübingen (F1300) and in CBS. Paratype: Germany, Baden-Württemberg, Tübin- gen, dried culture derived from an individual of the bark beetle Pityogenes chalcographus (L.) from Picea abies (L.) Karst., 3 May 1996, R. Kirschner 156 (FR). Habitats: Galleries of bark beetles (Crypturgus cinereus (Hrbst.), Crypturgus pusillus (Gyll.), Dryocoetes autographus (Ratz.), Hylurgops palliatus (Gyll.), Ips typographus (L.), Pityogenes chalcographus (L.), Orthotomicus laricis (F.), Polygraphus poligraphus (L.), Trypodendron lineatum (Olivier)) inhabiting conifers (Picea abies (L.) Karst. and Pinus sylvestris L.).

Geographical distribution. Germany, Italy, Switzerland. 

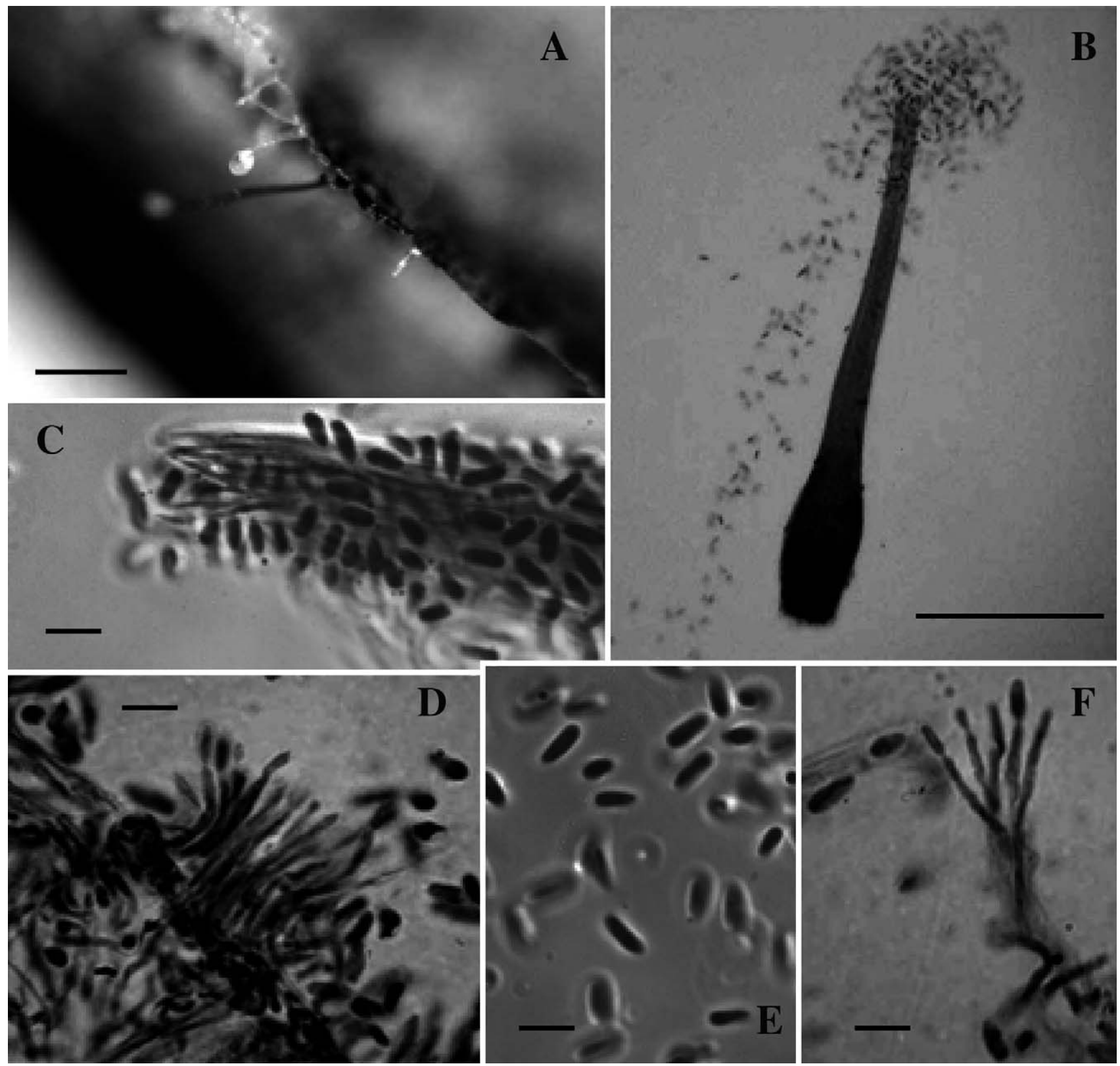

FIG. 3. Photographs of Proceropycnis pinicola. A. Pycnidia arising from the natural substratum showing their typical slimy droplet at the apex of the neck. B. Shape of the pycnidium with a squashed apical slimy droplet of conidia. C. Detail of ostiolar hyphae with emergent conidia. D. Mycelial tuft of conidiophores at the pycnidial base. E. Conidia. F. Branched conidiophores from pycnidium. Bars: $\mathrm{A}=200 \mu \mathrm{m}, \mathrm{B}=80 \mu \mathrm{m}, \mathrm{C}-\mathrm{F}=10 \mu \mathrm{m}$.

Proceropycnis M. Villarreal, Arenal, V. Rubio, Begerow, R. Bauer, R. Kirschner et Oberw., gen. nov.

Nomen anamorphosis, coelomycetibus pertinens. Fructificatio pycnoidea, cornuta, longa, hyalina, glabra, ostiolata, ex hyphis septatis composita. Collum hyalinum hyphis ostiolaribus. Conidiophora cavitatem pycnoideam circumdantia, ramosa, cellulis conidiogenis terminalibus et lateralibus hyalinis, parietibus laevibus, non ramosis. Conidia cylindracea vel subcylindracea, unicellularia, hyalina, apicibus rotundatis et truncatis basibus. Teleomorphosis ignota.
Typus generis. Proceropycnis pinicola M. Villarreal, Arenal, V. Rubio, Begerow, R. Bauer, R. Kirschner et Oberw., in opere ipso descripta.

Proceropycnis pinicola M. Villarreal, Arenal, V. Rubio, Begerow, R. Bauer, R. Kirschner et Oberw., sp. nov.

FIGS. 3-4

Etym. Referring to the slender pycnidia and the original habitat.

Conidiomata superficialia, pycnoidea, minuta, 172- 


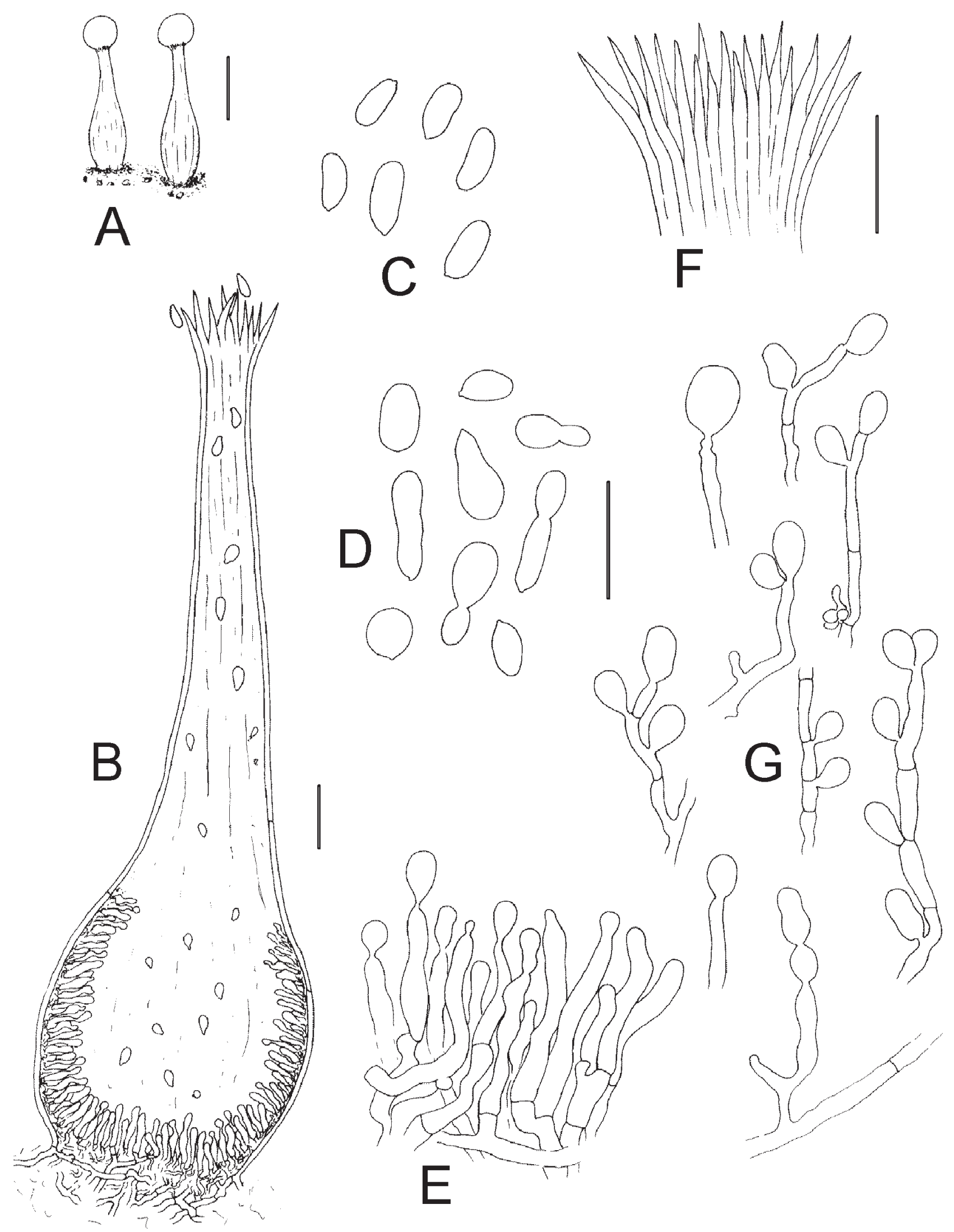

FIG. 4. Drawings of Proceropycnis pinicola. A. Pycnidia arising from the natural substratum. B. Detail in vertical section of the pycnidium. C-D. Mature conidia at the pycnidium and in pure culture, respectively. E. Mycelial tuft of conidiophores 
$425 \times 52-100 \mu \mathrm{m}$, sparsa vel gregaria, ex hyphis septatis hyalinis composita, glabra et ostiolata, ad basim vestigio mycelii albi. Hyphae muri pycnidii septatae, usque ad $3 \mu \mathrm{m}$ latae. Collum cylindraceum, $112-300 \times 10-50 \mu \mathrm{m}$ latum, hyphis ostiolaribus laevibus, divergentibus, apicaliter acuminatis usque ad $2 \mu \mathrm{m}$ latis. Conidiophora cavitatem pycnoideam circumdantia, ad basem colli conidiomatis inclinata, simplicia vel ramosa et septata. Cellulae conidiogenae terminales et laterales, hyalinae, $13-35 \times 1.5-2 \mu \mathrm{m}$. Conidia (5-)6-9 $\times 2-3(-4) \mu \mathrm{m}$, cylindracea vel subcylindricea, recta vel leniter curvata, apicibus rotundatis et truncatis basibus. Mycelium vegetativum hyphis ramosis, septatis, albis ad hyalinis, parietibus laevibus, $18-38 \times 2-3 \mu \mathrm{m}$. Coloniae in agaro malto albae usque ad hyalinae, 39-46 mm diam post 14 dies ad $23 \mathrm{C}$, hyphis aeriis et immersis. Status teleomorphicus non observatus.

Typus. In subere Pini pineae. Spain, Almorox (Toledo), 850 m, 13-X-2002. Leg. M. Villarreal, exsiccata in Herbario AH (AH33906, Holotypus) et TUB (TUB12091, Isotypus).

Paratypi. China, Yunnan, near Pu Er, ca. 1550 m, bark beetle galleries in bark of Pinus sp., 11 Aug 2001, R. Kirschner, Z.-L. Yang et al 1050 (KUN), Taiwan, Taipei, Peitou, in galleries of bark beetles or weevils in bark of Pinus sp., 17 Jul 1999, R. Kirschner 543 (TNM).

Conidiomata scattered to gregarious, superficial on the natural substrate and on autoclaved spruce twigs embedded in $1.5 \%$ water agar. Pycnidia (172) 250 $425 \mu \mathrm{m}$ long, cylindrical to flask shaped, with a swollen basal region 52-120 $\mu \mathrm{m}$ long and 33$75 \mu \mathrm{m}$ wide, hyaline or watery white to pale yellow, with a single elongated smooth neck, (112)170 $273(300) \times(10) 14-20(50) \mu \mathrm{m}$, usually straight but sometimes slightly curved, tapered upward and apically provided with ostiolar hyphae up to $2 \mu \mathrm{m}$ wide. Pycnidium wall made of septate and hyaline hyphae in parallel arrangement, up to $3 \mu \mathrm{m}$ wide, with slightly thickened walls, running continuously through the neck and finally forming the ostiolar hyphae at the apex. Neck up to $50 \mu \mathrm{m}$ wide with numerous ostiolar hyphae (15-30), straight to slightly sinuose and tortuose, smooth, up to $2 \mu \mathrm{m}$ broad, acuminated at the apex, and somewhat divergent in largest pycnidia (FIGS. 3A-C; 4A, B, F).

Conidiophores occurring in the base of the pycnidium, ascending somewhat through the inner layer of the wall, up to neck base, septate, clampless and hyaline (FIG. 4B). Mycelial tufts of conidiophores also developed out of the pycnidia at the base, arising from the mycelia. Septa separating lateral hyphal branches or conidiogenous cells in many cases not at the somewhat constricted insertion of branching but within the lateral cell at a certain distance from the supporting hypha. Conidiogenous cells terminal and lateral, $13-35 \times 1.5-2 \mu \mathrm{m}$, cylindrical or slightly tapered, somewhat sinuose, truncate at the apex, but without any apparent collarette or annellidic structure. Several conidia are produced by each conidiogenous cell, leaving fibrillar wall remains in the apex of the conidiogenous cell after conidium detachment (visible in TEM only). Conidia (5-)6-9 $\times 2-3(-4) \mu \mathrm{m}$, embedded in a hyaline or pale yellow slimy droplet at the apex of the neck, dikaryotic, hyaline, 1-celled, cylindrical or somewhat ellipsoid to comma shaped, with truncate base (FIGS. 3D-F; 4C-E, G).

Colonies on MEA, growing superficially and somewhat immersed, hyaline to white or pale to pale yellowish, sometimes hairy to floccose and glistening as a result of the slimy conidial mass; agar media not pigmented; reaching 39-46 $\mathrm{mm}$ diam after two wk at 24 C. Mycelial hyphae up to $3 \mu \mathrm{m}$ wide, straight to sinuose, septate, smooth-walled and terminal articles $18-38 \times 2-3 \mu \mathrm{m}$.

Teleomorphic state not observed.

Habitat. On wood of Pinus pinea and P. pinaster, in beetle galleries in bark of Pinus spp., together with Ophiostoma ips (Rumbold) Nannf., O. deltoideosporum (Olchow. \& J. Reid) Georg Hausner, J. Reid \& Klassen, O. minus (Hedgc.) Syd. \& P. Syd., O. sejunctum M. Villarreal, Arenal, V. Rubio \& M. de Troya and O. piceae (Münch) Syd. \& P. Syd.

Geographic distribution. Spain, China, Taiwan. Material studied. Spain: Almorox (Toledo), 850 m, 13-X-2002. Leg. M. Villarreal, AH33906 (Holotype) on wood of Pinus pinea, TUB12091 (Isotype); El Escorial (Madrid), 1000 m, 7-III-2003. Leg. M. Villarreal, AH33907 on wood of Pinus pinaster. China: Yunnan, near $\mathrm{Pu} \mathrm{Er}$, ca. 1550 m, bark beetle galleries in bark of Pinus sp., 11 Aug 2001, R. Kirschner, Z.-L. Yang et al 1050 (KUN). Taiwan: Taipei, Peitou, in galleries of bark beetles or weevils in bark of Pinus sp., 17 Jul 1999, R. Kirschner 543 (TNM). Living cultures of the strains from Spain are deposited in the CCMA culture collection (CCMA/VR-1331), and Merck, Sharp \& Dohme (CIBE F-158,681).

$\leftarrow$

arising from the mycelia developed at the pycnidial base. F. Detail of ostiolar hyphae. G. Conidiophores bearing conidia in different stages of development. Bars: $\mathrm{A}=75 \mu \mathrm{m}, \mathrm{B}-\mathrm{G}=10 \mu \mathrm{m}$. 

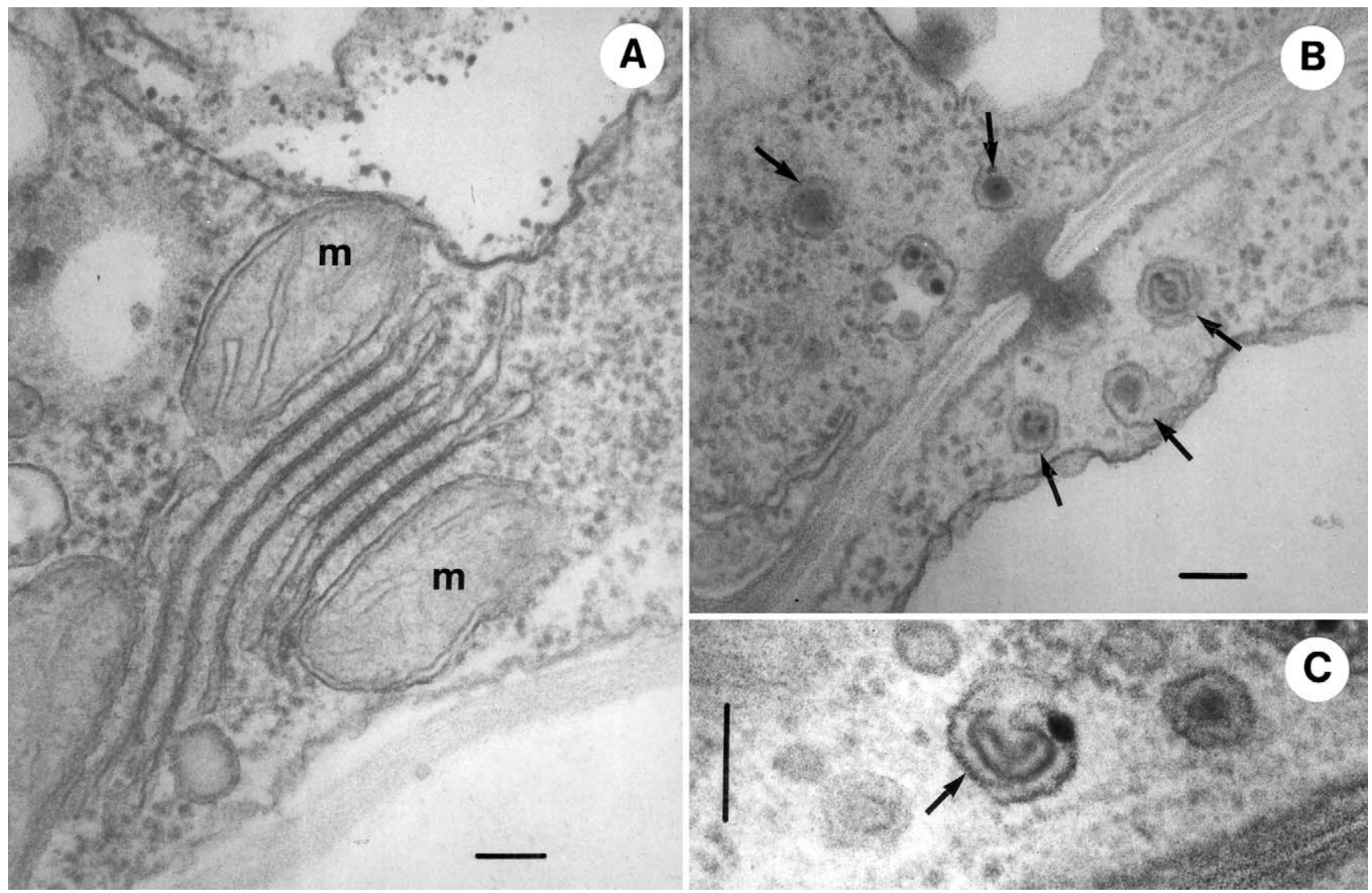

FIG. 5. Ultrastructural characteristics of Basidiopycnis hyalina. A. Symplechosome connected with mitochondria (m). B. Septal pore apparatus with an organelle-free zone delimited by atractosomes (arrows). C. Median section through an atractosome (arrow). Note that the atractosome is composed of a curved cisterna. Bars $=0.1 \mu \mathrm{m}$.

Conidiogenesis and morphology.-Because erecting a new genus of anamorphic fungi requires the type of conidiogenous cell to be studied in detail, we compared conidiogenesis in both new species. The anamorph of B. hyalina produces synnemata with annellidic conidiogenous cells and conidia in slimy heads (FIG. 2C-E). Hyaline synnemata with annellidic conidiogenous cells having affinities to the Ascomycota and not exhibiting the pattern of hyphal branching of the anamorph of Basidiopycnis hyalina are known in Graphilbum H.P. Upadhyay \& W.B. Kendrick (Upadhyay and Kendrick 1975) and Remersonia Samson \& Seifert (Seifert et al 1997). In the ascomycetous anamorphs the septum usually is placed directly at the insertion of the hyphal branch at the supporting hypha without a conspicuous constriction. In many basidiomycetous anamorphs the septum is formed within the hyphal branch at a certain distance from the insertion point (Kirschner 2004). This point of insertion usually is constricted. Similar basidiomycetous anamorphs are known in Stilbotulasnella Oberw. \& Bandoni (Bandoni and Oberwinkler 1982) and Pistillaria Fr. (Koske and Perrin 1971). We were not able to find morphological characteristics sufficient for separating these basidiomycetes anamorphs on a generic level and, therefore, do not propose a new genus for the anamorph of B. hyalina.

Conidiogenesis is more difficult to clarify in the other new taxon, $P$. pinicola. In light microscopy the apex of the conidiogenous cell in $P$. pinicola appears truncate, without discernable apical wall thickenings, collarettes, or annellations. Conidiogenesis could be deduced only with TEM studies. In TEM (not illustrated) a small collarette-like structure composed of fibrillar wall material is visible. The structure does not form compact apical wall thickenings as in phialides with conidiogenesis of the apical replacement wall-building mode according to Minter et al (1983) but appears similar to annellations at approximately the same level as described for Cryptosporiopsis sp. and Phoma fumosa Ell. \& Ev. by Sutton and Sandhu (1969). They stated that the sequence in development is not as clear as in other species. This type is intermediate between the phialidic one with apical-wall thickenings, where conidia secede successively from the same level of the apex of the conidiogenous cell, and the annellidic one, where 

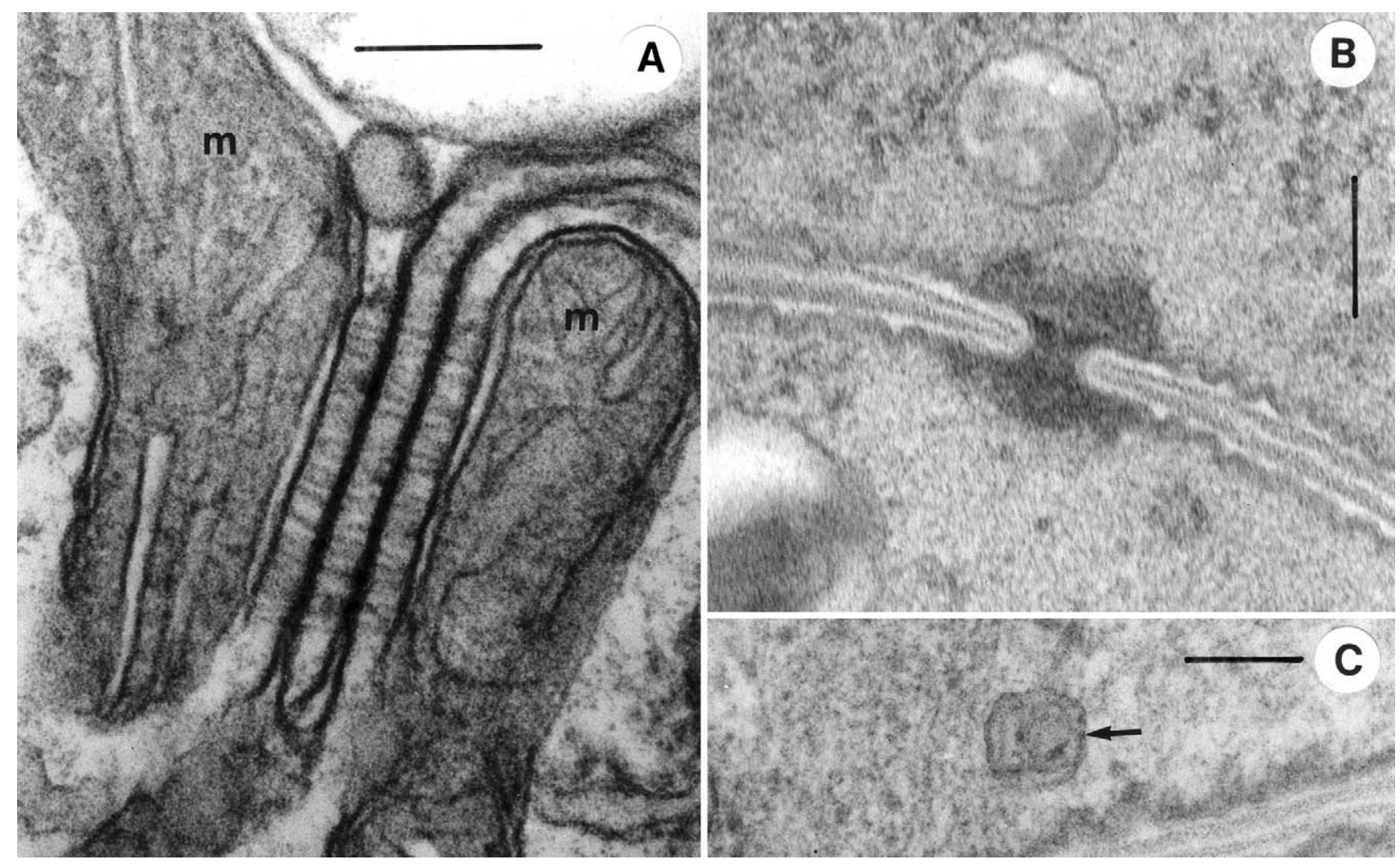

FIG. 6. Ultrastructural characteristics of Proceropycnis pinicola. A. Symplechosome connected with mitochondria (m). B. Septal pore apparatus with an organelle-free zone. One atractosome is sectioned. C. Section through an atractosome (arrow). Note that the atractosome is composed of a curved cisterna. Bars $=0.1 \mu \mathrm{m}$.

the youngest conidium secedes at a certain distance above the delimiting septum of the previous conidium (Minter et al 1982). This intermediate type is reported rarely and seems to be identical to what is called "spent wall thickening" in Phialocephala dimorphospora W.B. Kendr. by Mouton et al (1993) where wall remnants remaining in the collarette after conidium dehiscence are only loosely aggregated, whereas wall remnants adhere closely to each other in the common phialide with apical wall-thickening (Mouton et al 1993).

Basidiopycnis hyalina produces phragmobasidia inside its pycnidia (FIGS. 1A, 2A) and therefore is morphologically similar to Heterogastridium pycnidioideum Oberwinkler \& Bauer (Oberwinkler and Bauer 1990). H. pycnidioideum is distributed widely and has been reported several times from different habitats, but the presence of basidia and basidiospores were observed only in one of the known strains. Information on teleomorphic morphology therefore is based only on the sexual features of one collection in which the hymenium of the pycnidia is formed by a mixture of phragmobasidia and conidiophores, producing simultaneously both sexual and asexual structures inside the same fruiting body (Oberwinkler and
Bauer 1990). In contrast B. hyalina produces its anamorphic state in synnemata separately from the basidiomata (FIGs. 1B, 2C-E). This type of asexual structure is closer to synnemata occurring in some Atractiella species, where conidial synnemata produced are similar to the basidiomata (Bandoni and Inderbitzin 2002).

Proceropycnis pinicola is reported from similar habitats. It produces exclusively anamorphic states, where the pycnidia show only asexual structures (FIG. 4B). The structure of the pycnidial wall formed by hyaline, parallel and sparsely septate hyphae is nearly identical in both species and therefore seems to be homologous. The superficial cornute pycnidium is considered a special type of conidiomata by Søchting and Sutton (1997), who listed several coelomycetous genera and described a new one with this morphology. Consulting the monograph of coelomycetes by Sutton (1980) and other references, we compared Proceropycnis with additional genera with superficial cornute pycnidia. Proceropycnis pinicola develops superficial cornute pycnidia that are hyaline, in contrast to the majority of described taxa, and with a different micromorphology of conidiophores and conidia. 


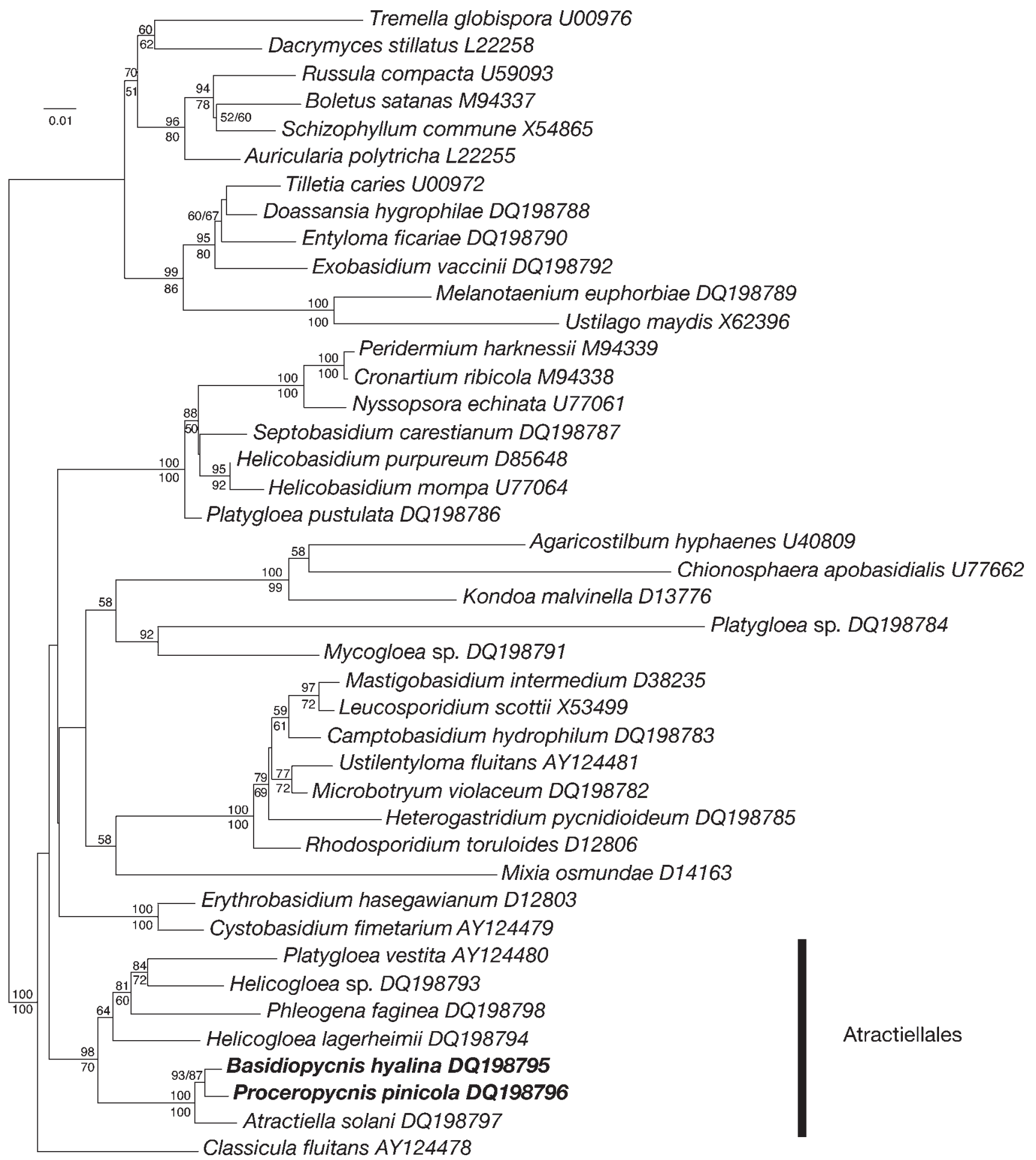

FIG. 7. Phylogeny: topology obtained by neighbor joining analysis of nuclear SSU sequences using GTRIG distances. Percentage bootstrap values of 1000 replicates are given at each furcation (neighbor joining values above and maximum parsimony values below). Ustilaginomycetes and Hymenomycetes were used as outgroup; values smaller than 50\% are not shown. Branch lengths are scaled in terms of expected numbers of nucleotide substitutions per site.

The conidial development and conidiophores are quite similar in Heterogastridium and Proceropycnis but differ from those in Basidiopycnis. Conidiophores in Heterogastridium and Proceropycnis cluster in a basal tuft, being simple or branched, within the pycnidium and out at the base in mycelial tufts. In both cases conidiogenous cells appear as cylindric or slightly tapered and constricted near the apex. In spite of 
TABLE II. Genetic distances of some Atractiellales

\begin{tabular}{lccc}
\hline \hline & B. hyalina & P. pinicola & A. solani \\
\hline Basidiopycnis hyalina DQ198779 & - & & - \\
Proceropycnis pinicola DQ198780 & 0.12289 & 0.09862 & - \\
Atractiella solani DQ198781 & 0.10200 & 0 \\
\hline
\end{tabular}

Pairwise distances were calculated based on the Kimura-2-parameter model of ITS sequences after removing five positions with gaps.

morphological similarities, H. pycnidioideum is not closely related to $B$. hyalina and $P$. pinicola.

Ultrastructure.-Within the basidiomycetes, the Atractiellales are unique in having symplechosomes (Bauer and Oberwinkler 1991, Oberwinkler and Bauer 1989, Weiss et al 2004). Therefore formation of symplechosomes in both Basidiopycnis hyalina and Proceropycnis pinicola (FIGS. 5A, 6A) clearly indicates that these fungi are members of the Atractiellaes. In addition, as in the members of Atractiella, Helicogloea and Phleogena the simple septal pores of Basidiopycnis hyalina and Proceropycnis pinicola are surrounded by atractosomes (Weiss et al 2004) in a more or less circular arrangement (Figs. 5B, C, 6B, C). At least in the type of Saccoblastia, S. farinacea, the aєtractosomes are substituted by microbodies (Weiss et al 2004). The uredinalian septal pore architecture in Saccoblastia suggests that this genus is in a basal position within the Atractiellales. Atractosomes originate from cisternae of the endoplasmic reticulum; a cisterum curves at the margin to form a globular compartment, the atractosome (Weiss et al 2004; FIGS. 5C, 6C). During this process electron-opaque material usually is added at the periphery of the actractosomes. However in Basidiopycnis hyalina and Proceropycnis pinicola the atractosomes appear to be simpler structures, lacking the additional material at the periphery (Figs. 5C, 6C).

Molecular phylogeny. - The analyses of the SSU rDNA sequences confirm previously published phylogenies of Basidiomycota (Begerow et al 1997, Bauer et al 2003). The monophyly of Urediniomycetes is supported with $100 \%$ for neighbor joining and maximum parsimony analyses. Previously described groups such as Urediniomycetidae, Microbotryomycetidae or Agaricostilbomycetidae are supported as well. However the topology of the backbone is poorly resolved, which is also the case in other studies (Weiss et al 2004). The Atractiellales seem to be monophyletic (FIG. 7). Basidiopycnis hyalina and Proceropycnis pinicola appear within the Atractiellales in a sister relationship with Atractiella solani. The other pycnidioid heterobasidiomycete Heterogastridium pycnidoideum (Oberwinkler and Bauer 1990) is well separated and belongs to the Microbotryomycetidae (FIG. 7).

The analysis of the ITS sequences (TABLE II) reveals a high genetic divergence between Basidiopycnis hyalina and Proceropycnis pinicola. They differ in 45 of $403 \mathrm{bp}$, which is similar to their differences to Atractiella solani (38 bp and $37 \mathrm{bp}$, respectively). The genetic distances of these three species are in the same range (TABLE II).

The molecular analysis of SSU and ITS sequences confirms the morphological, ecological and ultrastructural observations. The two pycnoid taxa are closely related and belong to the Atractiellaceae. But their genetic distance justifies a separation in two separate genera.

Ecology._Basidiopycnis hyalina was found in galleries and obtained in cultures derived from several bark beetles infesting conifers in temperate regions in Germany, Italy and Switzerland. The fungus appears to be widely distributed in central Europe and hitherto was not found outside this area. It was not found to be associated with bark beetles infesting angiosperms (data not shown). Proceropycnis pinicola was not found in central Europe but appears in species of Pinus infested by beetles in regions with very different climate, such as typical Mediterranean and subtropical environments (Spain, southwestern China, and Taiwan). The reasons underlying the different distributions of these two species are not known.

Both fungi develop in the bark beetle galleries and show the high diversity of basal lineages of Urediniomycetes associated with this habitat (Kirschner 2001; Kirschner et al 1999, 2001a, b, c). Basidiospores of $B$. hyalina are not forcibly discharged. The spores are passively released and aggregate at the apex of the basidioma in a slimy drop and the conidia of both $B$. hyalina and $P$. pinicola also aggregate in slimy drops at the apex of the pycnidia and conidiophores, respectively. Sexual and asexual spores therefore 
easily can become attached to the surface of the beetles and be dispersed by them.

A sexual stage was not found for $P$. pinicola but might be found in collections in other areas of the world. Basidiomata of B. hyalina were found directly in the bark beetle galleries. They develop in culture only in the presence of other fungi, but structures indicating a possible mycoparasitic interaction were not found. It might be a The situation might be similar in certain other members of the Urediniomycetes (e.g. species of Chionosphaera Cox [Kirschner et al 2001c]).

\section{ACKNOWLEDGMENTS}

We thank Drs Z.-C. Chen, M. Faccoli, A. Honold, B. Wermelinger and Z.-L. Yang for help in sample collecting; S. Köber for providing parts of SSU sequences and J. Götze and M. Wagner-Eha for technical assistance. The study was supported by the DFG-projects Organismische Interaktionen in Waldökosystemen KI 697/1-2 and OB 20/1-2 the German Academic Exchange Service (DAAD) and the National Science Council of Taiwan.

\section{LITERATURE CITED}

Bandoni RJ, Oberwinkler F. 1982. Stilbotulasnella: a new genus in the Tulasnellaceae. Can J Bot 60:1875-1879. , Inderbitzin P. 2002. On a new Atractiella. Czech Mykol 53(4):265-273.

Bauer R, Oberwinkler F. 1991. The symplechosome: a unique cell organelle of some Basidiomycetes. Bot Acta 104:93-97.

— Begerow D, Oberwinkler F. 2003. Classicula: the teleomorph of Naiadella fluitans. Mycologia 95:756764 .

Begerow D, Bauer R, Oberwinkler F. 1997. Phylogenetic studies on the nuclear large subunit ribosomal DNA of smut fungi and related taxa. Can J Bot 75:2045-2056.

Boysen M, Borja M, del Moral C, Salazar O, Rubio V. 1996. Identification at strain level of Rhizoctonia solani AG4 isolates by direct sequence of asymmetric PCR products of the ITS regions. Curr Gen 29:174-181.

Edgar RC. 2004. MUSCLE: multiple sequence alignment with high accuracy and high throughput. Nucl Ac Res 32(5):1792-97.

Gargas A, Taylor JW. 1992. Polymerase chain reaction primers for amplifying and sequencing nuclear $18 \mathrm{~S}$ rDNA from lichenized fungi. Mycologia 84:589-592.

Katoh K, Misawa K, Kuma K, Miyata T. 2002. MAFFT: a novel method for rapid multiple sequence alignment based on fast Fourier transform. Nucl Ac Res 30:3059-3066.

Kirschner R. 2001. Diversity of filamentous fungi in bark beetle galleries in central Europe. In: Misra JK, Horn BW, eds. Trichomycetes and other fungal groups: Professor Robert W. Lichtwardt commemoration volume. Enfield, NewHampshire: Science Publishers Inc. p 175-196.
2004. Sporodochial anamorphs of species of Helicogloea. In: Agerer R, Piepenbring M, Blanz P, eds. Frontiers in Basidiomycote mycology. Eching: IHW-Verlag. p 165-178.

— heterobasidiomycetous genus based on a species vectored by conifericolous bark beetles. Mycologia 91: $538-543$.

$\longrightarrow,-$ - 2001a. Colacosiphon: a new genus described for a mycoparasitic fungus. Mycologia 93: 634-644.

— sphaera species associated with conifer inhabiting bark beetles. Mycol Res 105:1403-1408.

— Sampaio JP, Gadanho M, Weiss M, Oberwinkler F. 2001c. Cuniculitrema polymorpha (Tremellales, gen. nov. and sp. nov.), a heterobasidiomycete vectored by bark beetles, which is the teleomorph of Sterigmatosporidium polymorphum. Antonie van Leeuwenhoek 80: 149-161.

Koske RE, Perrin PW. 1971. Basidiocarps, annelloconidia, and sclerotia in agar cultures of Pistillaria (Clavariadelphaceae). Can J Bot 49:695-697.

Minter DW, Kirk PM, Sutton BC. 1982. Holoblastic phialides. Trans Br Mycol Soc 79:75-93.

- - - 1983. Thallic phialides. Trans Br Mycol Soc 80:39-66.

Mouton M, Wingfield MJl, van Wyk PS. 1993. Conidium development in Phialocephala dimorphospora and a new pattern of wall thickening. Mycol Res 97:99-104.

Oberwinkler F, Bauer R. 1989. The systematics of gasteroid, auricularioid heterobasidiomycetes. Sydowia 41:224256.

- -1990 . Heterogastridiales: a new order of basidiomycetes. Mycologia 82:48-58.

Posada D, Crandall KA. 1998. Modeltest: testing the model of DNA substitution. Bioinformatics 14(9):817-818.

Seifert KA, Samson RA, Boekhout T, Louis-Seize G. 1997. Remersonia, a new genus for Stilbella thermophila, a thermophilic mould from compost. Can J Bot 75: 1158-1165.

Søchting U, Sutton BC. 1997. Scolecotheca cornuta gen. et sp. nov. on needles of Picea abies from Denmark. Mycol Res 101:1366-1370.

Sutton BC. 1980. The Coelomycetes. Oxon, UK: CAB International Inc.

— Sandhu DK. 1969. Electron microscopy of conidium development and secession in Cryptosporiopsis sp., Phoma fumosa, Melanconium bicolor, and M. apiocarpum. Can J Bot 47:745-749.

Swann EC, Frieders EM, McLaughlin DJ. 2001. Urediniomycetes. In: McLaughlin DJ, McLaughlin EG, Lemke PA, eds. Mycota VII. Part B. Systematics and evolution. Berlin, Heidelberg: Springer Verlag. p 37-56.

Swofford DL. 1998. PAUP*: phylogenetic analysis using parsimony (*and other methods). Sunderland, Massachusetts: Sinauer Associates.

Upadhyay HP, Kendrick WB. 1975. Prodromus for a revision of Ceratocystis (Microascales, Ascomycetes) and its conidial states. Mycologia 67:798-805. 
Weiss M, Bauer R, Begerow D. 2004. Spotlights on heterobasidiomycetes. In: Agerer R, Piepenbring M, Blanz P, eds. Frontiers in Basidiomycote mycology. Eching: IHW-Verlag. p 7-48.

White TJ, Bruns TD, Lee S, Taylor JW. 1990. Amplification and direct sequencing of fungal ribosomal RNA genes for phylogenetics. In: Innis MA, Gelfand DH, Sninsky JJ, White TJ, eds. PCR protocols, a guide to methods and applications. San Diego: Academic Press. p 315-322. 